\title{
Effect of different levels of Amla powder (Emblica officinalis) on the performance of broilers
}

\author{
AJAI KUMAR TIWARI, NEERAJ, KULADIP PRAKASH SHINDE AND SHAILESH KUMAR GUPTA
}

\begin{abstract}
Amla powder (Emblica officinalis) is an important source of vitamin C. This research was done at Sundaresen School of Animal Husbandry and Dairying, Sam Higginbottom Institute of Agriculture, Technology and Sciences, Allahabad, Uttar Pradesh. The aim of this study was to determine weekly body weight and weekly feed intake supplemented with vitamin C powder in following different levels. A total of 45 day old chicks (DOC) of same hatch were distributed into five groups i.e. $\mathrm{T}_{0}$ (Control), treatments $T_{1} T_{2} T_{3}$ and $T_{4}$ with three sub groups comprising of three birds. $T_{0}$ (control) were fed with standard ration recommended by NRC. The birds of $\mathrm{T}_{1}, \mathrm{~T}_{2}, \mathrm{~T}_{3}$ and $\mathrm{T}_{4}$ were supplemented ration with supplemented with $25 \mathrm{~g}, 50 \mathrm{~g}, 75 \mathrm{~g}$ and $100 \mathrm{~g}$ Amla powder $/ \mathrm{kg}$ feed. In conclusion concluded that there was a beneficial effect of Amla powder supplementation in the diet of broilers on body weight and feed intake of broilers. From economic point of view ration supplemented with vit c @ $100 \mathrm{~g} / \mathrm{kg}$ feed was found the best compared to all the treatments.
\end{abstract}

KEY WORDS : Amla powder, Growth, Body weight, Broiler, Chicks

HOW TO CITE THIS PAPER : Tiwari, Ajai Kumar, Neeraj, Shinde, Kuladip Prakash and Gupta, Shailesh Kumar (2016). Effect of different levels of amla powder (Emblica officinalis) on the performance of broilers. Res. J. Animal Hus. \& Dairy Sci., 7(1) : 16-19: DOI: 10.15740/HAS/ RJAHDS/7.1/16-19.

Address for correspondence :

Kuladip Prakash Shinde, Division of Livestock Production and Management, ICAR- NDRI, KARNAL (HARYANA) INDIA

Email : kuls164@gmail.com

Associated Authors' :

Ajai Kumar Tiwari and Neeraj, Department of Animal Nutrition, Sam Higginbottom Institute of Agriculture Technology and Sciences, ALLAHABAD (U.P.) INDIA

Email : ajaitiwari111222@gmail.com; neeraj.neeraj@shiats.edu.in

Shailesh Kumar Gupta, Division of Livestock Production and Management, ICAR- NDRI, KARNAL (HARYANA) INDIA

Email : sgshailesh786@gmail.com 